\title{
Evaluation of adult immunological outcomes from kimironko health center art program, 2007 to 2008
}

Andre H Mbayiha

From $16^{\text {th }}$ International Symposium on HIV and Emerging Infectious Diseases

Marseille, France. 24-26 March 2010

\section{Background}

ARTservices are expanding in Sub Saharan African countries. In Rwanda the demographic and health survey of 2005(DHS) showed a prevalence rate of 3\%at national level and by the end of June 2009, 70234 persons had initiated ARV at 217 sites in Rwanda (TRACnet report June 2009). Kimironko health center has provided care and treatment to patients since 2003, at this point there are 1776 patients followed in the HIV clinic at this health center. It is important to evaluate immunologic responses and efficacy of antiretroviral therapy in resource poor settings.

\section{Methods}

We conducted a retrospective cohort study to assess immunological outcomes among adult patients who initiated ART from January 1, 2007 to December 31, 2008. 426 patients were eligible for the study and data were analyzed using Epi info 3.2.2 and SPSS 17.

\section{Results}

The median age of our patients at ART initiation was 34 years and $66,9 \%$ were female. At ART initiation the median baseline CD4+ cell count was 192 cells per micro liter, the median CD4+ cell count increased by 90 cells per micro liter at 6 months $(\mathrm{n}=393)$ [interquartile range (IQR) 191-372] and 112 cells per micro liter [IQR 230-408] at 12 months $(\mathrm{n}=266)$. Women had higher median baseline CD4 cell counts than men (197 vs. 176/ $\mu \mathrm{L})$. First-line ART regimens contained Lamivudine (100\%), Stavudine (68,3\%), Zidovudine (31\%), and either Efavirenz (14\%) or Nevirapine (85,7\%).

Correspondence: andre.mbayiha@aidshealth.org

AIDS Healthcare Foundation, Kigali, Rwanda

\section{Discussion}

These data demonstrate robust and sustained CD4 response to ART among patients continuing on therapy. Despite not having viral load testing, using CD4 criteria alone indicates efficacy of first line therapies. Public health and programmatic interventions leading to earlier HIV diagnosis and initiation of ART could substantially improve patient outcomes in resource-limited settings.

Published: 11 May 2010

doi:10.1186/1742-4690-7-S1-P27

Cite this article as: Mbayiha: Evaluation of adult immunological

outcomes from kimironko health center art program, 2007 to 2008. Retrovirology 2010 7(Suppl 1):P27.
Submit your next manuscript to BioMed Central and take full advantage of:

- Convenient online submission

- Thorough peer review

- No space constraints or color figure charges

- Immediate publication on acceptance

- Inclusion in PubMed, CAS, Scopus and Google Scholar

- Research which is freely available for redistribution

Submit your manuscript at www.biomedcentral.com/submit
C Biomed Central 